Original Research Paper

\title{
Petrophysical Properties Distribution Modelling of an Onshore Field, Niger Delta, Nigeria
}

\author{
Godwin Omokenu Emujakporue \\ Department of Physics, University of Port Harcourt, Rivers State, Nigeria
}

Article history

Received: 22-11-2016

Revised: $21-03-2017$

Accepted: 30-03-2017

Email: owin2009@yahoo.com

\begin{abstract}
This research is based on the modelling of petrophysical parameters distribution of an onshore oil field in Niger Delta. The methodology involves the construction of 3-D grids that represent the reservoir geometry, accompany by property modeling where the 3-D grids were populated with petrophysical properties (porosity, water saturation, net to gross ratio, facies and permeability). The objective is to construct a 3D-dimensional reservoir model that characterizes and evaluate reservoirs in an onshore oil field, Niger delta. Three-dimensional grid and geophysical logs of 4 oil boreholes were used to characterize the delineated reservoirs. Two lithologies and two reservoirs were delineated from the logs. The lithologies are sandstone and mudstone which are arranged in alternation representing the Agbada Formation of the Niger Delta. The calculated petrophysical parameters for the two reservoirs in the four wells were used for estimating the properties distribution in the reservoirs. The petrophysical properties estimation and distribution was done with inverse distance weighting of deterministic techniques of modeling. The calculated porosity values for the two reservoirs range from 0.061 to 0.30 with an average of 0.185 . The permeability of the two reservoirs ranged from 110 to $2394 \mathrm{mD}$. The calculated water saturation and net to gross ratio of the two reservoirs range from $0.23-0.57$ with an average of 0.4 and $0.44-0.87$ with an average of about 0.61 respectively. The porosity, permeability, water saturation and net to gross ratio and facies models show uniform distribution within the reservoirs. From the models, it can be inferred that the reservoir properties within the central part of the field are very good. It is, therefore, advisable that wells should be drilled in the central region to investigate the presence of oil. The results of this study have shown the effectiveness of $3 \mathrm{D}$ reservoir modeling as a tool for understanding the spatial distribution of reservoir properties. The results can be used as a guide for evaluating future performance and production behavior of the reservoirs.
\end{abstract}

Keywords: Petrophysical Properties, Reservoir, Modeling, Deterministic, Inverse Distance Weighting

\section{Introduction}

Porosity, permeability and water saturation are the main petrophysical properties of a reservoir rock and have a vital impact on hydrocarbon reservoir evaluation and characterization. To evaluate hydrocarbon reserves, there is a need for accurate determination of porosity, water saturation and pore volume and recovery factor. Petrophysical properties have a reasonable contribution to reservoir estimation, therefore it needs a serious attention. Reservoir characterization is the integration of different data in order to describe the reservoir properties of interest in inter-welllocations (Mehdipour et al., 2013; Ezekwe and Filler, 2005; Hadi et al., 2005). Various petrophysical properties such as porosity, net-to-gross and water saturation are used for reservoir modeling. Hydrocarbon reservoirs properties can be estimated by deterministic and probabilistic modeling (Godwill and Waburuko, 2016; Perevertailo et al., 2015; Kelka and Perez, 2002; Ezekwe and Filler, 2005; Başel et al., 2010). Petrophysical parameters can be derived from geophysical $\operatorname{logs}$ or core samples. Porosity can be obtained from sonic, neutron or bulk density log while resistivity logs are used for the calculation of water 
saturation. Models have been derived for the computation of permeability from porosity data.

Formation evaluation involves qualitative and quantitative interpretation of geophysical logs in order to determine some of the petrophysical properties of the reservoir rock, such as porosity, water saturation and permeability and lithology. Petrophysical modeling is very important in fluid flow analysis in the reservoir. Reservoir property modeling can be done by deterministic and stochastic methods. Spatial distribution of petrophysical properties in the reservoir is difficult to predict deterministically (Miller et al., 2000; Ma et al., 2013; Adeoti et al., 2014; Qihong et al., 2000). The deterministic techniques involve inverse distance weighting and Kriging. The inverse distance techniques were adopted for the work. The deterministic techniques assume single value at a point. Hence, prediction of the spatial occurrence of rock properties via stochastic process ought to be done for effective numerical modeling of physical properties. The primary objective of geological characterisation is to enable the prediction of spatial variation in the geological model away from the borehole. The sampled point is the only location where the data from the well is honored and all the data away from the well is extrapolated (Fanchi, 2010; Rotimi et al., 2014; Weiqi and Quanhou, 2015; Xiangyang et al., 2001). A deterministic model, when simulated, will give similar results as to the input data.

A comprehensive petrophysical evaluation is necessary to optimize development and production. In this study, petrophysical parameters in the onshore field, Niger Delta were evaluated using wireline logs. This study is divided into two parts: The first is a quantitative evaluation of reservoir properties (porosity, water saturation and permeability) in the wells while the second part concern estimating and predicting the spatial variation of the reservoir properties. The objectives of the present work are delineate hydrocarbon reservoir, estimate the petrophysical parameters within the reservoirs and model their lateral distribution.

\section{Summary of the Geology of the Study Area}

The study area is located within the Niger Delta sedimentary basin (Fig. 1), within longitudes $05^{\circ} 41^{\prime} 27^{\prime}$ ' $\mathrm{E}$ to $05^{\circ} 42^{\prime} 05^{\prime \prime} \mathrm{E}$ and latitudes $05^{\circ} 51^{\prime} 55^{\prime \prime} \mathrm{N}$ to $05^{\circ} 52^{\prime} 03^{\prime \prime} \mathrm{N}$. The Niger Delta is one of the most prolific hydrocarbon areas in the world (Oyedele et al., 2013; Stacher, 1995). Some geologists and geophysicists have work on the hydrocarbon potential and distribution pattern of the Niger Delta (Chukwueke, 1997; Doust and Omatsola, 1990; Weber et al., 1973).

Three lithostratigraphies have been delineated in the basin: Benin, Agbada and Akata Formations. The Akata and Benin Formations form the base and top of the basin. Most hydrocarbon accumulation in the Niger Delta is confined to the Agbada Formation while the Akata Formation is the source rock (Ejedavwe et al., 1984; Evamy et al., 1978). The hydrocarbon reservoir in the Agbada Formation is due to the presence of growth faults and rollover anticlines which are critical trapping structures.

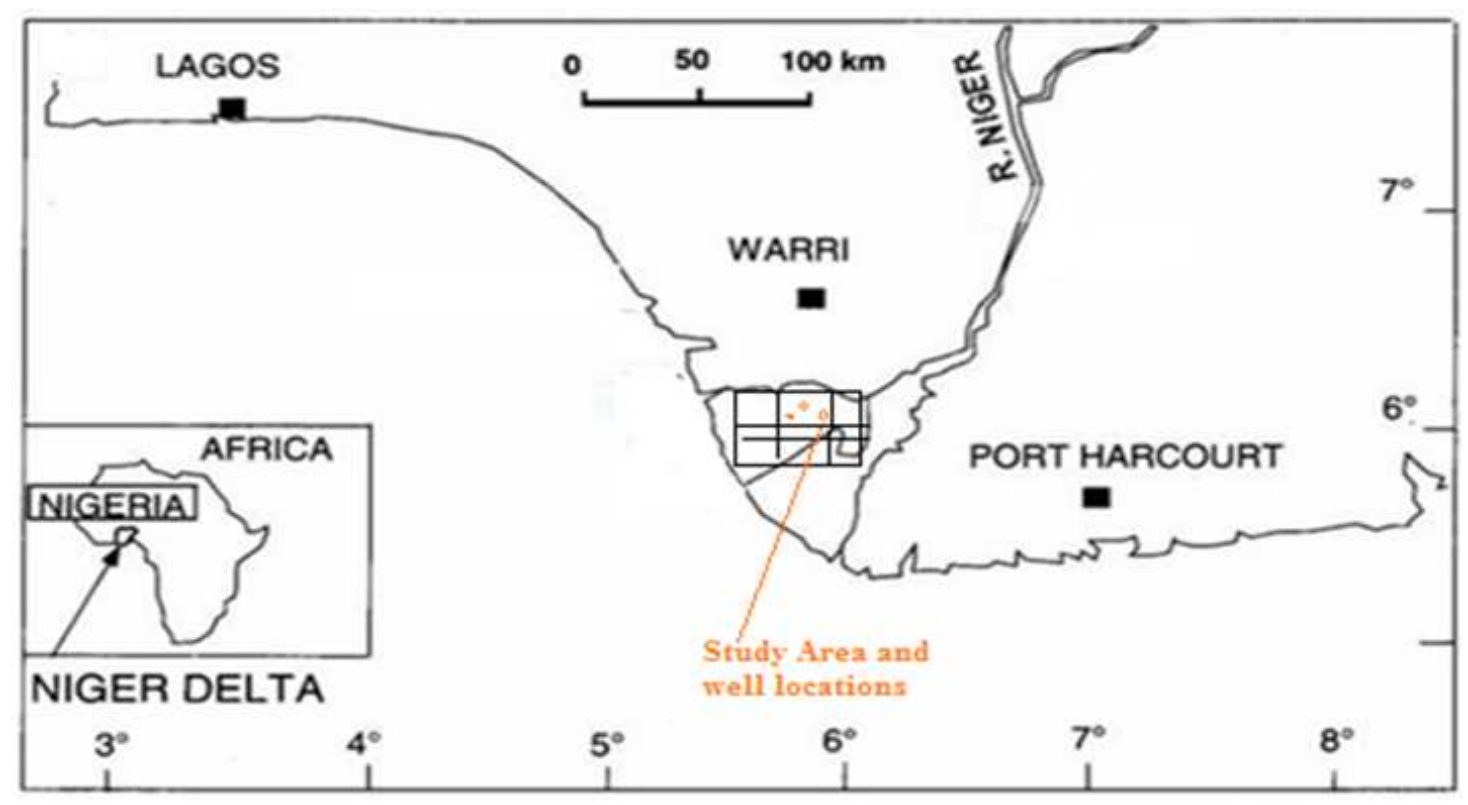

Fig. 1. Map of Niger Delta showing the location of the study area and positions of oil wells 


\section{Materials and Methods}

The data used for this work consists of four composite logs obtained from exploratory wells and 3D grid maps of the delineated reservoirs. Each of this suite of logs is made up of gamma-ray, resistivity, SP logs, bulk density and neutron porosity logs. The petrophysical evaluation was implemented using Petrel software. The well logs interpretation involves lithology and reservoir delineation, determination of porosity, water saturation, Net to Gross Ratio (NGS) and permeability. Static reservoir modeling was applied to the computed petrophysical data in order to distribute the petrophysical properties in the $3 \mathrm{D}$ grid. There are two types of interpolation techniques: Deterministic and geostatistic. The two techniques depend on the similarity of nearby sample points to create the surface. Deterministic methods use mathematical functions. In this study 'Inverse Distance Weighting' is used to generate petrophysical properties distribution maps.

\section{Lithology and Reservoir Delineation}

The Gamma-ray and resistivity logs were used for lithology and reservoir delineation. For the gamma ray $\log$, deflections to the left (low values) signify sandstone while the deflection to the right (high values) signifies shale. Irregular deflections represent intercalation of sands and shale. High values of resistivity correlating with a sandstone zone is an indication of a reservoir sand while low values represent shale or reservoir containing salt water. Reservoir sands were also characterized by decreasing neutron porosity values. The depth and thickness of the reservoir were also obtained from the gamma ray and resistivity logs.

\section{Porosity Determination}

Porosity is one of the primary parameter used for evaluating the amount of hydrocarbon in a reservoir. The porosity was derived from density log by using equation:

$\varphi=\frac{\ell_{m a}-\ell_{b}}{\ell_{m a}-\ell_{f}}$

Where:

$\varphi=$ Porosity derived from density log

$\ell_{m a}=$ Matrix density $\left(2.65 \mathrm{~g} / \mathrm{cm}^{3}\right)$

$\ell_{b}=$ Bulk density (as measured by the tool and hence includes porosity and grain density)

$\ell_{f}=$ Fluid density $(1 \mathrm{~g} / \mathrm{cm})$

\section{Determination of Water Saturation}

The fluid saturation of a reservoir is usually expressed as a function of the total pore space. The fluid in a reservoir may be saline water and/or hydrocarbon. The amount of water saturation in a reservoir is a function of the quantity of hydrocarbon in it. The higher the water saturation in the reservoir, the lower the amount of hydrocarbon.

Water saturation is the fraction of pore volume occupied by formation water. Archie's saturation equation is the basis for fluid saturation determination. Archie (1942) equation for determination of water saturation in clean sand is given in Equation 2 as:

$S_{w}^{n}=\frac{a^{*} R_{w}}{\varphi^{m} R_{t}}$

Where:

$S_{w}=$ Calculated water saturation percentage

$n=$ Saturation exponent

$R_{t}=$ The true formation resistivity

$a=$ Tortuosity

Archie's water saturation model has some limitations when used in sands that are not very clean (Udegbunam and Ndukwe, 1988). The limitations necessitated in seeking for a Saturation model that will improve on Archie's work and able to model water saturation in both clean and non-clean (shaly) sands. Thus Simandoux (1963) model was used in this study which adequately takes care of the limitations experienced by using Archie's model in shaly sands.

The main approach of this model is to solve the interpretation problem and to calculate saturation values free from the shale effect. This shale effect depends on the amount of shale content in the formation hence, the estimation of Volume of shale (Vsh) is very important. This model was developed for the interpretation of water saturation in shaly sands. The underlining Physics of the Simandous water saturation model is that the total conductivity of the formation depends on the conductivities of Water and Shale. Simandoux (1963) is as expressed in Equation 3:

$S_{W e}=\frac{C \times R_{W}}{\phi_{e}^{2}}\left[\sqrt{\frac{5 \phi_{e}^{2}}{R_{W} R_{t}}+\left(\frac{V_{c l}}{R_{s h}}\right)^{2}}-\frac{V_{c l}}{R_{s h}}\right]$

Where:

$S_{w e}=$ Effective (clay-corrected) water saturation

$\Phi e=$ Effective porosity corrected for clay

$R_{s h}=$ Resistivity of adjacent shale

$R_{w}=$ Formation water resistivity

$R_{t}=$ Deep formation resistivity

$V_{c l}=$ Volume of shale

$C=0.40$ for sandstones

The hydrocarbon saturation in the reservoir is determined by the difference between unity and fraction of water saturation (Asquith and Krygowski, 2004; Schlumberger, 1989). It is given as: 


$$
S_{h}=1-S_{w}
$$

In terms of percentage:

$S_{h}=1-S_{w} \%$

Where:

$S_{h}=$ Hydrocarbon saturation

$S_{w}=$ Water saturation

\section{Determination of Permeability}

The permeability values for the reservoir sands were calculated from Owolabi et al. (1994) equation:

$$
K(m D)=307+26552\left(\varphi^{2}\right)-34540\left(\varphi \times S_{w}\right)^{2}
$$

Where:

$K=$ Permeability

$\varphi=$ Porosity

$S_{w}=$ Water saturation

\section{Determination of Net-To-Gross}

Net-To-Gross is a measure of the potential of productive part of a reservoir. It is usually expressed either as percentage or fraction of the producible (net) reservoir within the overall (gross) reservoir packages. It varies from just a few percentages to $100 \%$ and it is expressed as:

$$
\text { Net }- \text { to }- \text { Gross }=\frac{N H}{G H}
$$

Where:

$N H=$ Net thickness

$G H=$ Gross thickness

Net Thickness $=$ Gross thickness-Shale thickness

\section{Deterministic Modelling}

It is one of the methods used for interpolating and estimating the value of a variable between two points at unsampled location. Deterministic modeling can be done by moving average or kriging techniques (Başel et al., 2010). The moving average method was adopted in this study and it is based on inverse distance weighting. The inverse weighted distance of a value decreases as the distance increases from the prediction location (Bailey and Gatrell, 1995; Isaaks and Srivastava, 1989). The inverse distance weighting is directly based on the surrounding measured values or on specified mathematical formulas that determine the smoothness of the resulting surface and values of closer points are weighted more heavily than those farther away. The inverse distance weighted formula is given as:

$$
Z_{o}=\frac{\sum_{i=1}^{n} \frac{1}{d_{i}} Z_{i}}{\frac{1}{d_{i}^{2}}}
$$

Where:

$Z_{o}=$ Estimated value of variable $Z$ in unsampled point

$Z_{i}=$ Sample value in point $i$

$d_{i}=$ Distance of sampled point to the estimated point

\section{Results and Discussion}

Three-dimensional models are becoming part of the techniques for assessing hydrocarbon reserves. A major element of the technique is the construction of 3-D grid that accurately represent reservoir geometry. The 3-D grid is followed by property modeling, in which the grid is populated with petrophysical properties such as porosity, water saturation and permeability. This modeling is based on the detailed analysis of subsurface data during reservoir characterization. The base map of the inline and cross line seismic sections and deep boreholes locations are shown in Fig. 2. The geophysical well $\operatorname{logs}$ were obtained from the cited boreholes. Qualitative interpretation of the geophysical logs shows that two major lithologies and reservoirs are present in the studied oil field (Fig. 3A and B). These lithologies are sandstone and mudstone which are alternated indicating the Agbada Formation of the Niger Delta. The two reservoirs are denoted as R1 and R2. The tops of the reservoirs RI and R2 occur at averagedepths of 3000 and $3300 \mathrm{~m}$ respectively. The green and the blue colours in the logs indicates the hydrocarbon and saline water intervals in the reservoirs.

\section{Property Modelling}

The 3-D grids constructed for the two reservoirs from seismic data of the study area are shown in Fig. 4. The observed faults in the seismic data are also indicated in the grid maps. To populate the grids with reservoir properties, the petrophysical properties of the wells were scaled up to assign a single averaged value for each grid cells. Petrophysical property values computed from the geophysical logs were sampled into the $3 \mathrm{D}$ grid in such a way that each grid cell has a single value for each property. Having assigned property values to each grid cell at boreholelocations, the next thing was to distribute properties in the interwell grid cells in order to realistically preserve the heterogeneity of the studied reservoir.

\section{Porosity Modeling}

Porosity is one of the primary parameter used for evaluating the amount of hydrocarbon in a reservoir. The computed average porosity from the four wells was used to estimate the porosity at unsampled locations and the results were distributed into the 3-D grid for property mapping as shown in Fig. 5. The dominant porosity values range from $0.2-0.7$ (light blue to yellow colours). Generally, the porosity is evenly distributed within the study area. The light blue colour is the zone of interest. 


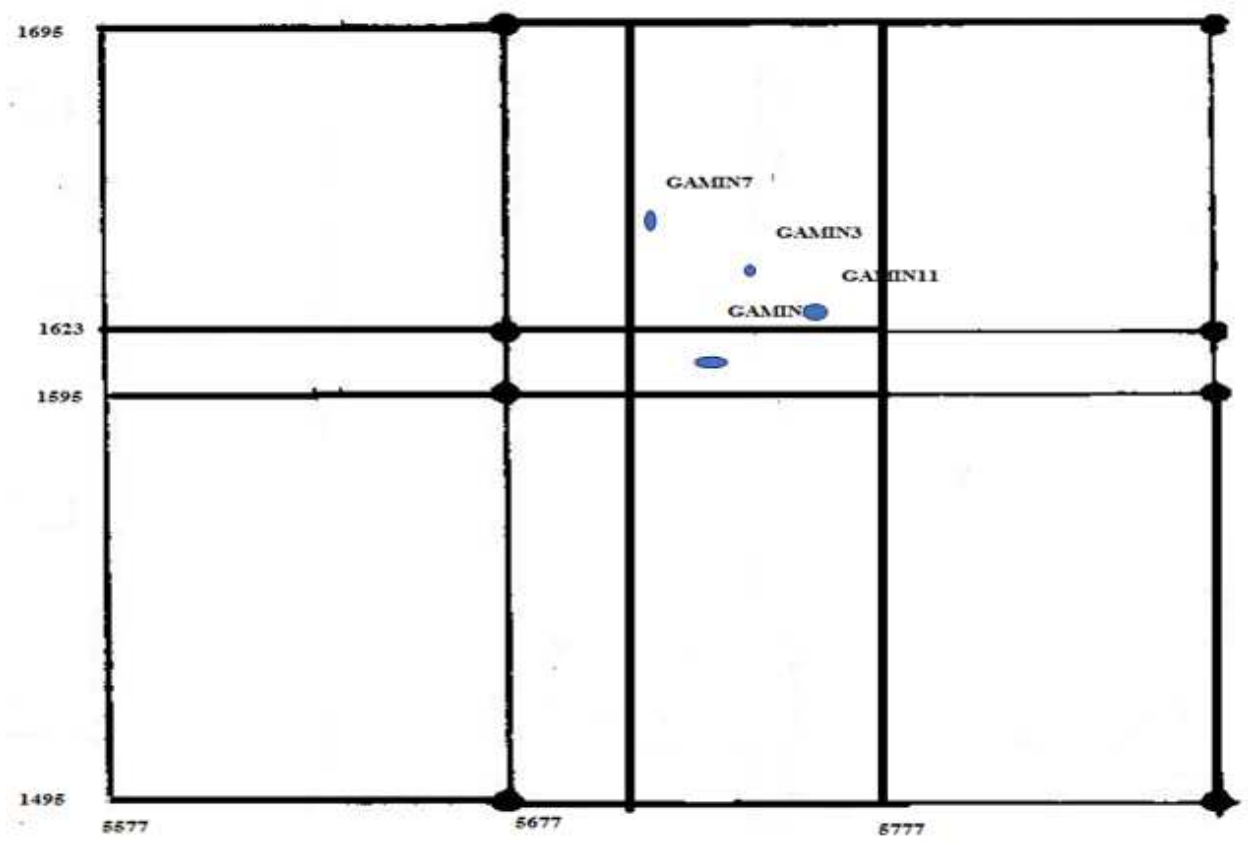

Fig. 2. Shows the in-line and cross lines of acquired seismic sections and well locations

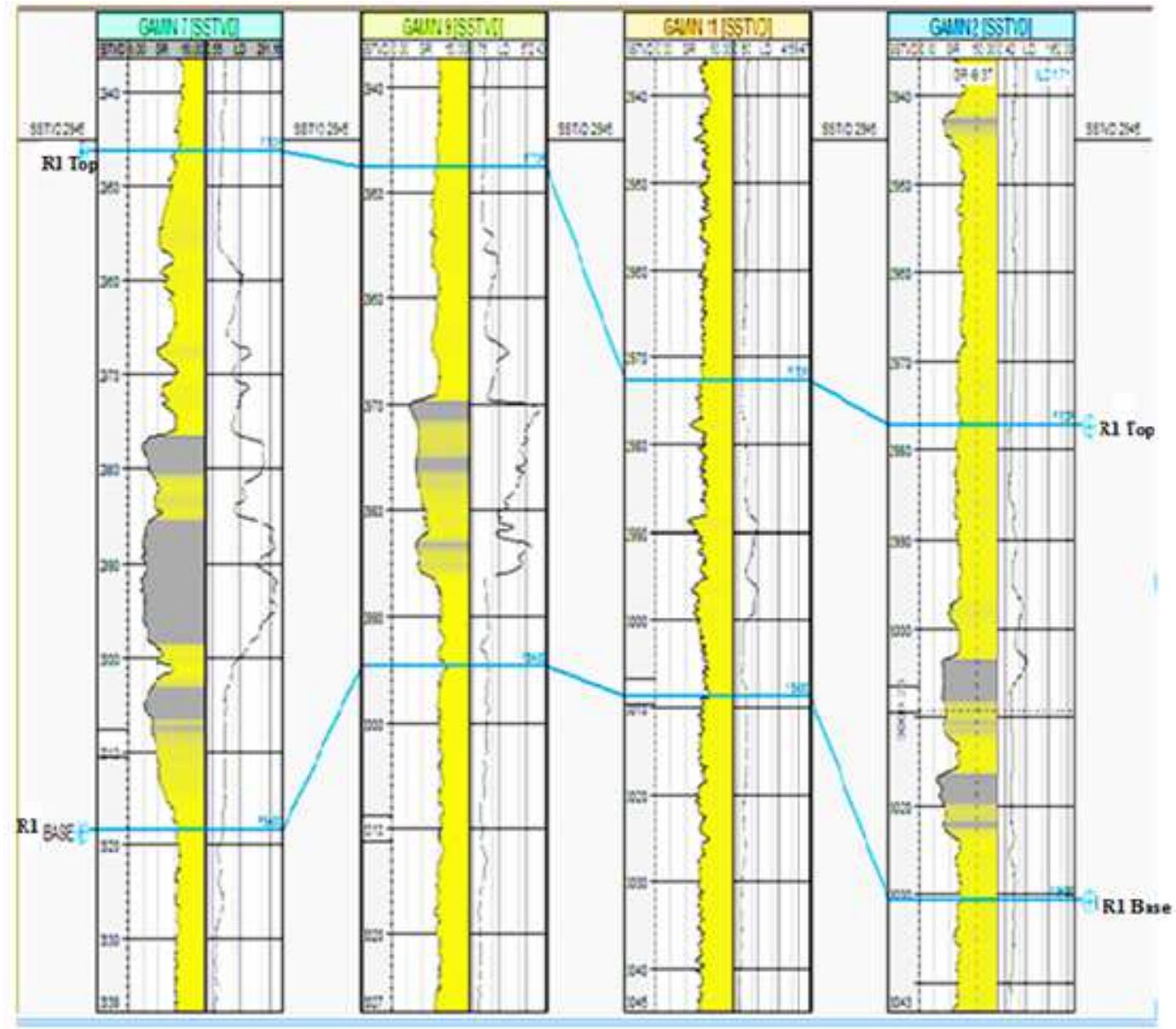

(a) 


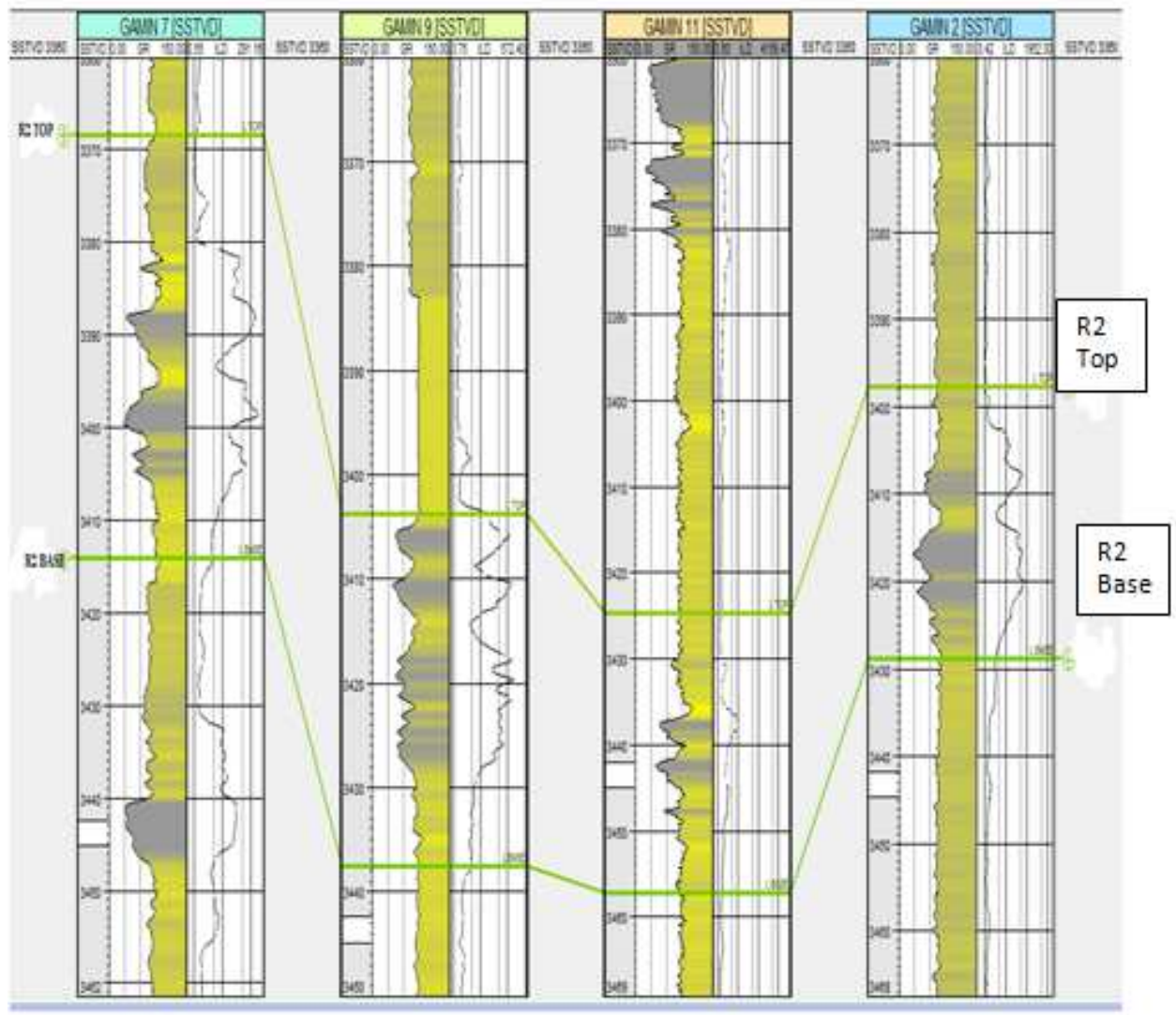

(b)

Fig. 3. (A) Well logs correlation panel for reservoir R1, (B) Well logs correlation panel for reservoir R2

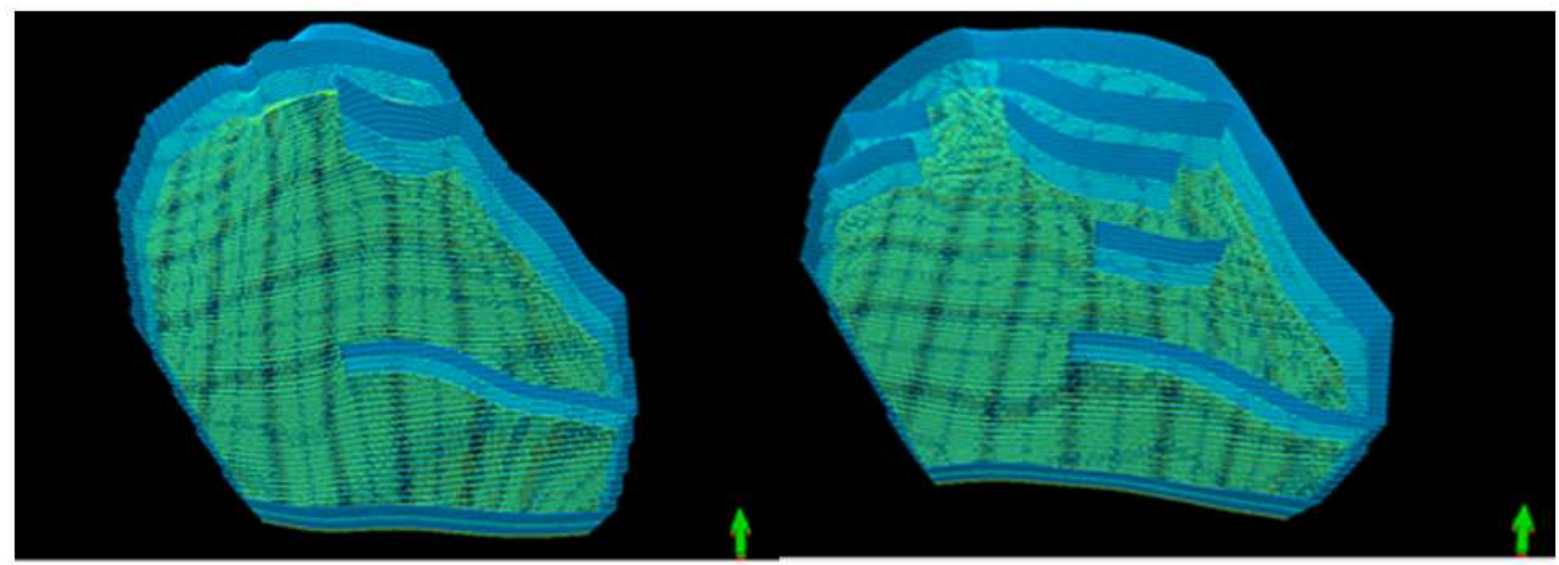

Fig. 4. 3-D Grid view for reservoirs R1 and R2

\section{Water Saturation Modeling}

Water saturation is also an important parameter in reservoir characterization. The hydrocarbon saturation is a function of the water saturation. The water saturation computed from the resistivity logs for each of the boreholes was used to estimate the values at unsampled locations and was distributed across the 3-D grids (Fig. $6)$. The calculated water saturation for the two reservoirs ranges from $0.23-0.57$. The average water saturation is about 0.4 . The water saturation is uniformly distributed like porosity in the reservoirs. The zones with low values (yellow and green) are of interest because they indicates high hydrocarbon saturation. 

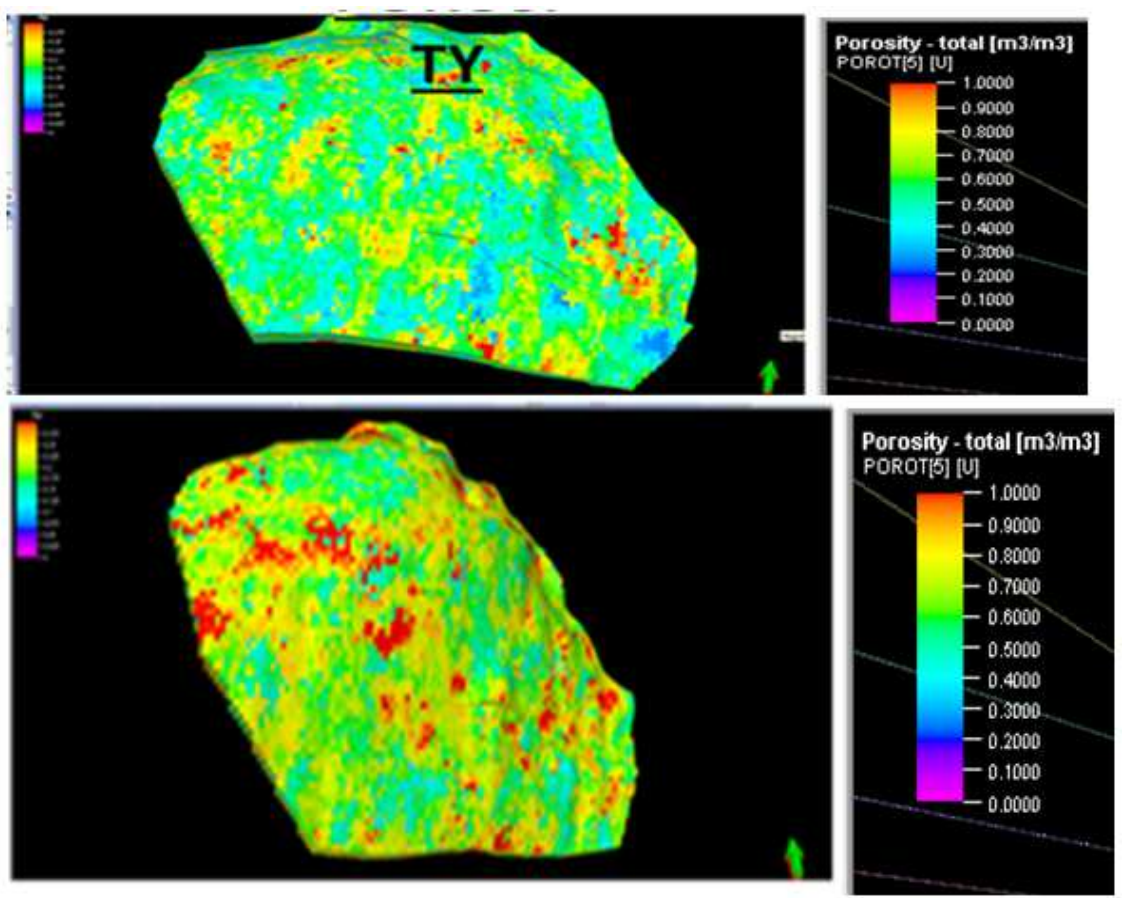

Fig. 5. Porosity model for reservoirs R1 and R2

\section{Sw}

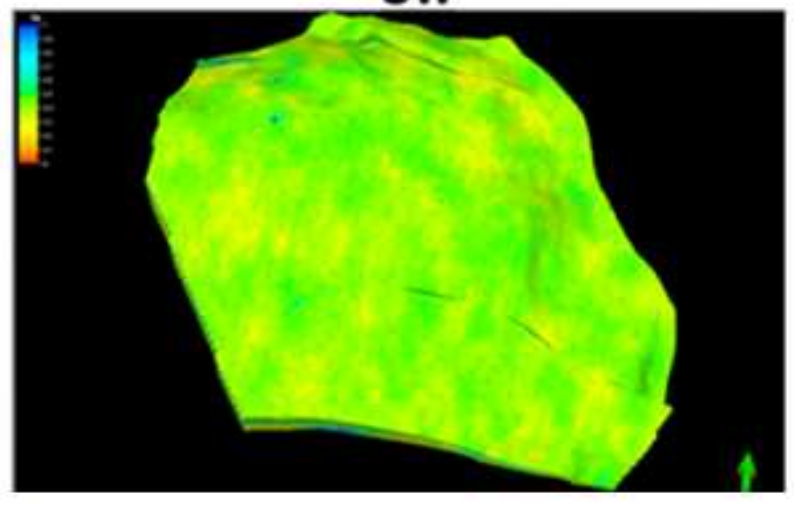

Water saturation

SwU[5] [U]
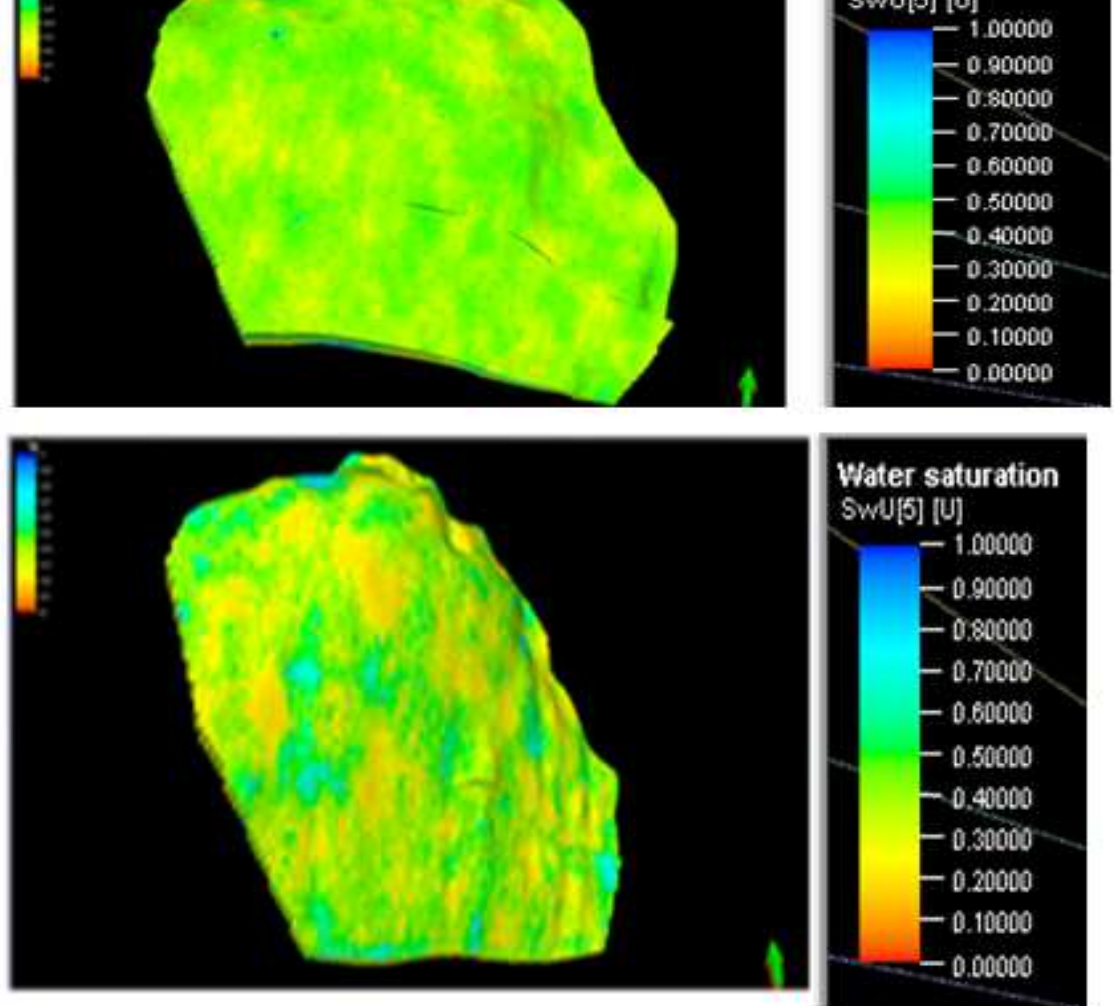

\section{Water saturation}

SWU[5] [U]

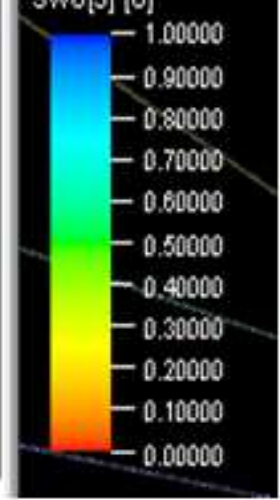

Fig. 6. Water saturation model for reservoirs R1 and R2 

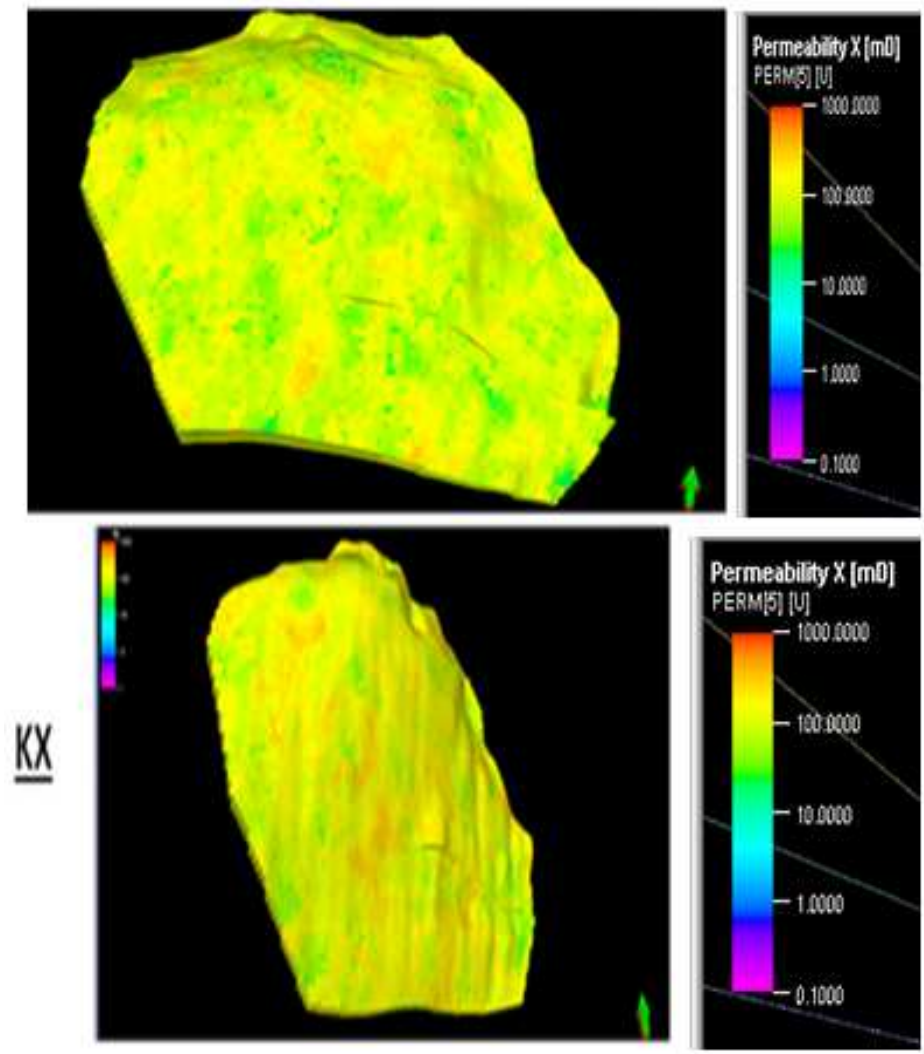

Fig. 7. Permeability model for reservoirs R1 and R2
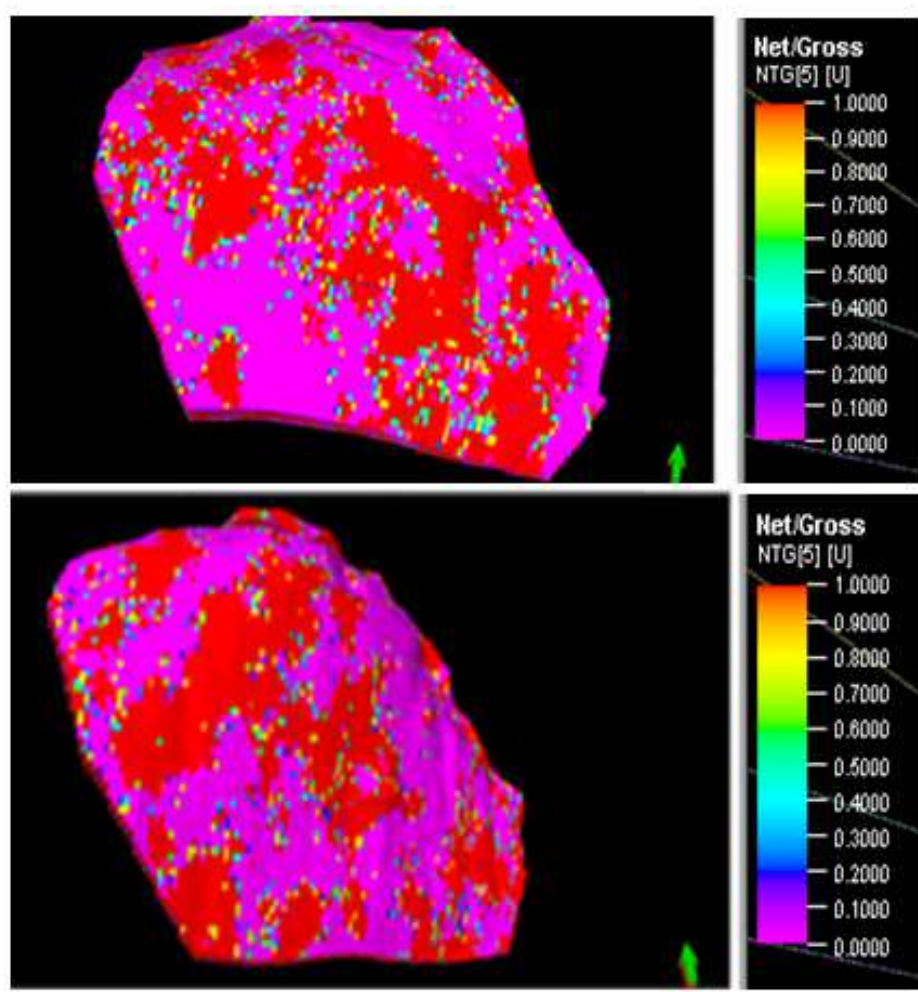

MetiGross NTO[5] [U]

-10000
-09000

$-0.8000$

$-0.7000$

$-0.6000$

$-0.5000$

$-0.4000$

$-0.3000$

$-0.2000$

$-0.1000$

$-0,0000$

Fig. 8. Net-to-Gross ratio model for reservoirs R1 and R2 

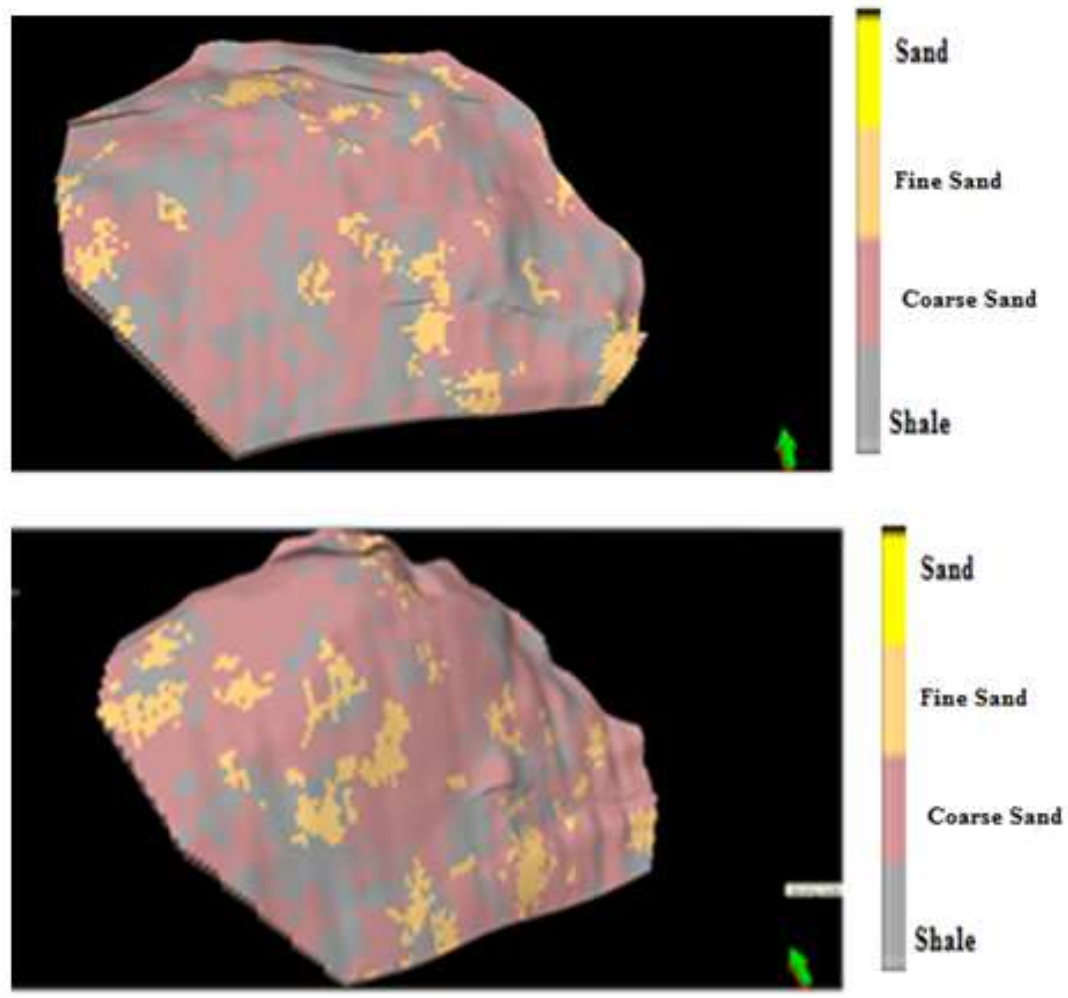

Fig. 9. Litho facies model for reservoirs R1 and R2

\section{Permeability Modeling}

Permeability is also very important for reservoir rock characterization. It is a measure of the ability of a formation to transmit fluids. The permeability of the two reservoirs ranged from 110-2394 $\mathrm{mD}$ (Fig. 7). The permeability is uniformly distributed in the area and the dominant ones are the green and yellow colours which have high values.

\section{Net to Gross Ratio}

The net to gross ratio model for reservoirs R1 and R2 are shown in Fig. 8. The net to gross ratio of the two reservoirs ranges from $0.44-0.87$ with an average value of 0.613 . The central regions of the reservoirs are dominated by the maximum (red colour) values.

\section{Facies Modeling}

Lithofacies modeling is very crucial in reservoir characterization. It is used for simulating the sand bodies in the formation. The delineated reservoirs are composed mainly of sandstone and some amount of shale content. The facies models for the two reservoirs are shown in Fig. 9. The models show the distribution of coarse sand (brown colour) and shale (grey colour) lithology within the reservoirs. The coarse grain sand is more dominant in the reservoirs.

\section{Conclusion}

This research work shows the important of reservoir modeling. The results of the petrophysical evaluation of the four wells show that two reservoirs and lithologies respectively were present in the oil field. The interpolation map of petrophysical properties using inverse distance weighting provide a single value model. The distributed estimated values represent the possible spatial distribution of the properties from the sampled points. The results of the porosity, water saturation, permeability, lithofacies and net to gross ratio modeling show that the properties. Most of the petrophysical parameters show uniform distribution within the two reservoirs. The petrophysical modeling has provided a better understanding of the spatial distribution of the petrophysical properties in the subsurface and the model could be used by reservoir engineers for simulation and guide for the reservoirs development.

\section{Acknowledgment}

I wish to acknowledge the Department of Petroleum Resources and Shell Petroleum Development Company, Nigeria for approving and releasing the data used for this work. 


\section{Funding Information}

There was no external financial support for the project research.

\section{Author's Contributions}

Godwin Omokenu Emujakporue: The research was solely carried out by the author.

\section{Ethics}

This article is original and contains unpublished material. No ethical issues and conflict of interest.

\section{References}

Adeoti, L., N. Onyekachi, O. Olatinsu, J. Fatoba and M. Bello, 2014. Static reservoir modeling using well $\log$ and 3-D seismic data in a $\mathrm{KN}$ field, offshore Niger Delta, Nigeria. Int. J. Geosci., 5: 93-106. DOI: $10.4236 /$ ijg.2014.51011

Archie, G.E., 1942. The electrical resistivity $\log$ as an aid in determining some reservoir characteristics. Petroleum Trans. AIME, 146: 54-62. DOI: $10.2118 / 942054-\mathrm{G}$

Asquith, G. and D. Krygowski, 2004. Basic Well Log Analysis. 2nd Edn., American Association of Petroleum Geologist, ISBN-10: 0891816674, pp: 244.

Bailey, T.C. and A.C. Gatrell, 1995. Interactive Spatial Data Analysis. 1st Edn., Longman Scientific and Technical, London, ISBN-10: 0582244935, pp: 413.

Başel, E., D. Korkmaz, A. Satman and U. Serpen, 2010. Predicted subsurface temperature distribution maps for Turkey. Proceedings of the World Geothermal Congress, Apr. 25-29, Bali, Indonesia, pp: 1-7.

Chukwueke, C.C., 1997. Factors controlling hydrocarbon distribution in the central swamp depobelt of the Niger Delta, Nigeria. Assoc. Petrol. Explorat. Bull., 12: 41-45.

Doust, H. and E.M. Omatsola, 1990. The Niger Delta. In: Divergent-Passive Margin Basins, Edwards, J.D. and P.A. Sentugross (Eds.), American Association of Petroleum Geologists, Tulsa, ISBN-10: 0891813268, pp: 201-238.

Ejedavwe, J.E., D.O. Lamnert-Aikhionbare and C. Okrie, 1984. Time of hydrocarbon generation and expulsion in Niger delta basin. NAPE. Bull., 10: 1-10.

Evamy, D.D., J. Harcmboure, P. Karmmerling, W.A. Kossp and F.A. Molloy et al., 1978. Hydrocarbon habitat of tertiary Niger delta. AAGP. Bull., 62: 1-39.

Ezekwe, J.N. and S.L. Filler, 2005. Modelling deep water reservoirs. Proceedings of the Annual Technical Conference and Exhibition, Oct. 9-12, Dallas, Texas, USA.
Fanchi, J.R., 2010. Integrated Reservoir Asset Management: Principles and Best Practices. 1st Edn., Gulf Professional Publishing, Burlington, ISBN-10: 0123820898, pp: 376.

Godwill, P.A. and J. Waburuko, 2016. Application of 3D reservoir modeling on Zao 21 oil block of zilaitun oil field. J. Pet Environ. Biotechnol., 7: 262-262. DOI: 10.4172/2157-7463.1000262

Hadi, J., C. Harrison, J. Keller and S. Rejeki, 2005. Overview of darajat reservoir characterization: A volcanic hosted reservoir. Proceedings of the World Geothermal Congress Antalya, Apr. 24-29, Turkey, pp: 1-11.

Isaaks, E.H. and R.M. Srivastava, 1989. An Introduction to Applied Geostatistics. 1st Edn., Oxford University Press, New York, pp: 561.

Kelka, M. and G. Perez, 2002. Applied Geostatistics for Reservoir Characterization. 1st Edn., Society of Petroleum Engineers, Richardson, ISBN-10: 1555630952, pp: 264.

Ma, S.M., M.M. Zeybek and F.J. Kuchuk, 2013. Integration of static and dynamic data for enhanced reservoir characterization, geological modeling and well performance studies. Saudi Aramco J. Techn. DOI: 10.2118/166492-MS

Mehdipour, V., B. Ziaee and H. Motiei, 2013. Determination and distribution of petro physical parameters (PHIE, Sw and NTG) of Ilam Reservoir in one Iranian oil filed. Life Sci. J., 10: 153-161.

Miller, R.B., J.W. Castle and T.J. Temples, 2000. Deterministic and stochastic modeling of aquifer stratigraphy, South Carolina. Groundwater, 38: 284-195. DOI: 10.1111/j.1745-6584.2000.tb00339.x

Owolabi, O.O., T.F. Longjohn and J.A. Ajienka, 1994. An empirical expression for permeability in unconsolidated sands of the eastern Niger delta. J. Petrol. Geol., 17: 111-116. DOI: 10.1111/j.1747-5457.1994.tb00117.x

Oyedele, K.F., D.O. Ogagarue and D.U. Mohammed, 2013. Integration of 3D seismic and well log data in the optimal reservoir characterization of EMI field, offshore Niger Delta oil province, Nigeria. Am. J. Sci. Ind. Res., 4: 11-21.

Perevertailo, T., N. Nedolivko, O. Prisyazhuyuk and T. Dolgaya, 2015. Application of geologicmathematical 3D modeling for complex structure deposits by the example of Lower-Cretaceous period depositions in Western Ust-Balykh oil field (Khanty-Mansiysk Autonomous District).

Qihong, L., S. Ziqi and T. Chengqian, 2000. Reservoir description of the stochastic simulation method. J. Xi'an Petrol. Inst., 15: 13-16.

Rotimi, O.J., B.D. Ako and Z. Wang, 2014. Reservoir characterization and modeling of lateral heterogeneity using multivariate analysis. Energy Explorat. Exploitat., 32: 527-552.

DOI: $10.1260 / 0144-5987.32 .3 .527$ 
Schlumberger, 1989. Basic Log interpretation, seminar. Texas, Schlumberger Limited.

Simandoux, P., 1963. Dielectric measurements on porous media, application to the measurement of water saturation: Study of the behaviour of argillaceous formations. Rev. I.Fr. Petrol., 18: 193-216.

Stacher, P., 1995. Present Understanding of the Niger Delta Hydrocarbon Habitat. In: Geology of Deltas: Rotterdam, Oti, M.N. and G. Postma (Eds.), August Aimé Balkema, pp: 257-267.

Udegbunam, E.O. and K. Ndukwe, 1988. Rock property correlations for hydrocarbon producing reservoir sands of the Niger Delta. Oil Gas J., 86: 55-58.
Weber, K., J. Merki and E.M. Daukoru, 1973. Petroleum geology of the Niger Delta. Proceedings of the 9th World Petroleum Congress, (WPC' 73), pp: 209-221. DOI: 10.1144/GSL.SP.1990.050.01.21

Weiqi, M. and L. Quanhou, 2015. Review on the modeling of oil and gas reservoir. IOSR J. Eng., 5: 14-16.

Xiangyang, H., X. Qihua and W. Shenghe, 2001. Reservoir modeling method research progress. J. Petrol. Univ., 25: 107-112. 